\title{
The Mediating Effect of Disclosure on the Relationship Between Corporate Governance Mechanisms and Firm Performance of Islamic Banks
}

Fahru Azwa Mohd Zain, Wan Amalina Wan Abdullah @ Muda, Norfadzilah Rashid

To Link this Article: http://dx.doi.org/10.6007/IJARBSS/v8-i12/5066

DOI: 10.6007/IJARBSS/v8-i12/5066

Received: 11 Nov 2018, Revised: 18 Dec 2018, Accepted: 28 Dec 2018

Published Online: 29 Dec 2018

In-Text Citation: (Zain, Muda, \& Rashid, 2018)

To Cite this Article: Zain, F. A. M., Muda, W. A. W. A. @, \& Rashid, N. (2018). The Mediating Effect of Disclosure on the Relationship Between Corporate Governance Mechanisms and Firm Performance of Islamic Banks. International Journal of Academic Research in Business and Social Sciences, 8(12), 696-715.

\section{Copyright: (C) 2018 The Author(s)}

Published by Human Resource Management Academic Research Society (www.hrmars.com)

This article is published under the Creative Commons Attribution (CC BY 4.0) license. Anyone may reproduce, distribute, translate and create derivative works of this article (for both commercial and non-commercial purposes), subject to full attribution to the original publication and authors. The full terms of this license may be seen at: http://creativecommons.org/licences/by/4.0/legalcode

Vol. 8, No. 12, 2018, Pg. 696 - 715 


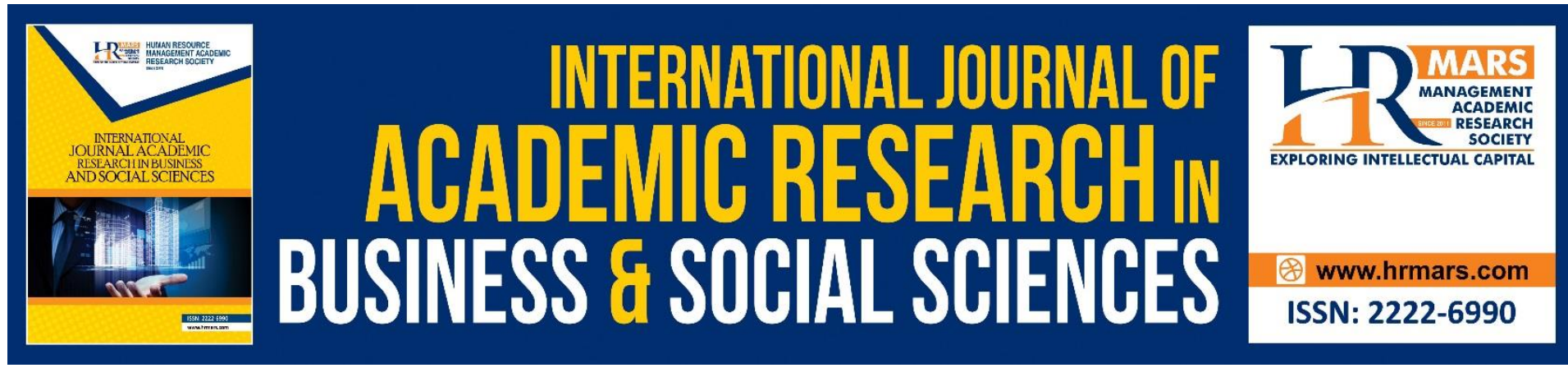

\title{
The Mediating Effect of Disclosure on the Relationship Between Corporate Governance Mechanisms and Firm Performance of Islamic Banks
}

\section{Fahru Azwa Mohd Zain, Wan Amalina Wan Abdullah @ Muda, Norfadzilah Rashid}

Faculty of Economics and Management Sciences, Universiti Sultan Zainal Abidin, 21300 Kuala Nerus, Terengganu, Malaysia

\begin{abstract}
This research investigates the relationship between corporate governance (CG) mechanisms and SSB mechanisms on the firm's performance of Islamic bank affected by the mediating variable of $C G$ disclosure. $C G$ is expected to be relevant to Islamic banks in strengthening the infrastructure of Islamic financial institutions (IFIs). Thought a limited amount of research against on CG and performance of Islamic banks has been carried out, this study tries to explore more on the CG and firm performance, particularly in the context of Islamic banks and CG disclosure as a mediating variable to strengthen this relationship. This paper aims to address CG disclosure as a mediating variable as a gap in this study. The empirical procedures involve panel data analysis is applied from the annual reports of Islamic banks in the Southeast Asian (SEA) and the Gulf Cooperation Council (GCC) regions from 2012 to 2017. Based on the reviews past literature, the result provides evidence that stronger CG strength and Shari'ah supervisory board (SSB) strength have a relationship with a higher level of firm performance of the Islamic bank. This study contributes to the literature regarding how CG disclosure as a mediating variable influences the relationship between CG strength, SSB strength and firm performance of Islamic banks.
\end{abstract}

Keywords: Corporate Governance, Disclosure, Firm Performance, Islamic bank

\section{Introduction}

Islamic banks have become an important sector that contributes to economic wealth and development in many countries. The recently issued competitiveness report of World Islamic Banking Competitiveness Report for the years 2016, by Ernst \& Young, showed that the sector achieved a growth of 16 per cent in terms of assets in the period between 2010 and 2014 (Ernst \& Young, 2016). Interestingly, the growth was significantly higher for Islamic banks than for conventional banks and is expected to reach an estimated value of USD 1.8 trillion in 2020 in the important major markets, which are the Gulf Cooperation Council (GCC), Malaysia, Indonesia, Pakistan, and Turkey (Ernst \& Young, 2016) 
The recent global financial crisis in the year 2007 and 2008 has received significant attention from several academics and practitioners (Erkens, Hung, \& Matos, 2012). They argue that the CG mechanism has resolved the conflict among stakeholder and management of the company, and the CG mechanism aims not functioned appropriately to preserve from stakeholders interest. Board of director and management of the company plays an important role in CG mechanism (Weiying \& Baofeng, 2008). Board of director and management of the organisation gives key and authority direction, appraisal of administration, target judgment and venture choice for the company (Adams, Hermalin, \& Weisbach, 2010). Attention to the CG mechanism increased recently by many scholars. CG mechanism as the fundamental internal mechanism has been mentioned in many kinds of literature (Ararat, Black, \& Yurtoglu, 2017; Basu \& Dimitrov, 2010; Bhagat \& Bolton, 2009; Black, Carvalho, Khanna, Kim, \& Yurtoglu, 2016). However, based on The Organisation for Economic Co-operation and Development (OECD) (2015) and The Basel Committee on Banking Supervision (BCBS) (2015) overseeing the management performances and supervising the company strategy do by the board of director and management of the company. The CG has been further categorised by the board of directors and management of the company.

In recent years, the $C G$ mechanism has received considerable attention in Islamic finance. The dimension of the CG mechanism in Islam which is different from the western concept refers to its fundamentals concept whereas, in the Islamic concept, it is based on the Shari'ah principle. The fundamental principles of tawhid, shura, property rights and commitment to a contractual obligation that govern the economic and social behaviour require IFIs to comply with the Shari'ah rules and principles (Darmadi, 2013; Grassa, 2015; Ratri \& Dewi, 2017; Thajudeen, 2013). At this stage, CG structure and disclosure in IFls need additional measures of governance for the purpose of Shari'ah compliance based on the Shari'ah principle, known as Shari'ah governance (SG) (Alkhamees, 2013). As part of the CG framework in IFIs, Shari'ah governance is the very essence of Islamic finance practice in building and maintaining the confidence of the shareholders and other stakeholders and assuring them that all transactions, practices and activities are in compliance with the Shari'ah principles and can be affected the financial performance of Islamic bank (Alkhamees, 2013; Hameed et al., 2016; Ratri \& Dewi, 2017).

Many researchers have studied the impact of CG mechanisms on firms' performance from different environments in the different perspectives using some variables of interest (AlMalkawi \& Pillai, 2018; Asutay \& Harningtyas, 2016; Budiman, Kristanti, \& Wardhana, 2016; Darmadi, 2013; Elsiddig, 2017; Ghayad, 2008; Hamza, 2013; Kasim, Nu Nu Htay, \& Ahmed Salman, 2016; Khamar Tazilah, Ahamad Rapani, Abdul Halim, \& Majid, 2017; Kusuma \& Ayumardani, 2016; Mollah, Hassan, \& Al-Farooque, 2014; Naushad \& Malik, 2015; Noordin, Kassim, Prabangasta, \& Hayeeyahya, 2015; Srairi, 2015). The researchers' found mixed results on the relationship between CG mechanisms, SSB mechanisms and firms' performance. For this study, CG and SSB mechanism have been translated to be CG strength and SSB strength. Furthermore, in this study, CG disclosures will be used as mediating variables to strengthen the relationship between CG and SSB strengths and firm performance of the Islamic banking. 


\section{Literature Review}

\section{Corporate Governance and Performance in Islamic Financial Institutions}

CG of IFIs allows ensuring fairness to all stakeholders through greater transparency and accountability towards Islamic principle. The CG of a Shari'ah business would first look at the transactional structure to see whether the transaction involves elements that invalidate gains or profits since Shari'ah principle is involved not only with the material but also with the form of business (Haider, Khan, \& Iqbal, 2015). In effect, CG for IFIs stems from two principal elements it is a faith-based approach that directives are running of the company in synchronisation with Shari'ah principle and a profit-motive that recognises company and investment transactions to the maximisation of shareholder's wealth (Elsiddig, 2017). Hence, the main feature of the CG in the IFIs is ensuring the compliance with the Shari'ah principle. The Effective CG may significantly help to strengthen Islamic banks and to assist Islamic banks in increasing rapidly and performing their responsibility efficiently (Elsiddig, 2017). CG on Islamic banking will become serious when the institutions more extensive. The problems become more complicated when the Islamic banks more extensive, which will doubt their ability. CG in Islamic banks can be leading better management in Islamic banks and to meet the challenges effectively that Islamic banking face.

The CG deals with the way how firms are managed and controlled and how accountability is assured. The efficiency of CG mechanisms in an Islamic bank organisation may help the company to reach its objectives, including its risk management and affect the financial performance of the Islamic bank (Mollah, Hassan, Al Farooque, \& Mobarek, 2016). The CG mechanism ensures the management acts in the best interest of the company and minimises the agency cost. The CG framework is one of the important keys to increasing the efficiency in business monitoring. The implementation of the CG mechanism is expected to attain a balance of many interests that give benefit to the company. Good financial performance is crucial for Islamic banking to be able to keep maintaining the existence of the banking listed as a viable investment for the banking sectors (Mollah \& Zaman, 2015). A study by Mollah et al. (2016) shows that the governance structure in Islamic banks agrees them to take higher risks and accomplish better performance as a result of item complexities and exchange instruments. However, the higher capitalisations in Islamic banks are maintained compared to conventional banks.

While there have been numerous studies on CG in the Islamic banking sector (Ahmed, Zalailah, Hafiza, \& Hashim, 2016; Alkhamees, 2013; Chapra \& Habib, 2002; Farag, Mallin, \& Ow-Yong, 2017; Grais \& Pellegrini, 2006; Grassa \& Matoussi, 2014; Nienhaus, 2003; Thajudeen, 2013), and there are studies has been written about the relationship between CG and their firm performance of Islamic banking (Bukair \& Abdul Rahman, 2015; Elsiddig, 2017; Ghayad, 2008; Haider et al., 2015; Yongqiang Li, Armstrong, \& Clarke, 2014; Mallin, Farag, \& Ow-Yong, 2014; Mollah et al., 2014, 2016; Mollah \& Zaman, 2015; Platonova, 2014; Srairi, 2015). Mollah et al., (2016) study about the difference in governance structures influences the risk-taking and performance of Islamic banks compared to conventional banks. In this study, Mollah et al., (2016) used 104 conventional banks and 52 Islamic banking from 2005 to 2013 in 14 countries for their sample. In this study, they determine that the governance structure in Islamic banks play an important function in risk-taking as well as firm performance that is different from conventional banks. Particularly, the achievement of better 
performance in Islamic banks in the transaction mechanisms and product complexities cause of the governance structure that has been complying.

\section{Corporate Governance and Disclosure}

In recent years, there has been an increasing interest in CG disclosure in Islamic banks and these lead, more standards have been used to confirm that all disclosed information needs to meet the standards which had been identified (Wan Ibrahim, Ismail, \& Wan Mohd Zabaria, 2011). These standards expose their business information and act as the guide to the banks formally or informally. There are many improvements in accounting, auditing, ethics, governance, and Shari'ah standards when Islamic banking is introduced. In this perspective, the international guideline like Accounting and Auditing Organisation for Islamic Financial Institutions (AAOIFI) are commonly used by the IFIs worldwide and responsible for preparing accounting and auditing standards (AAOIFI, 2010). To enhance the public trust in Shari'ah investment instruments, AAOIFI standards play an important role to promote transparency and comparability of annual report disclosure in IFIs. Amongst the standards are the objectives, concepts and general presentation and disclosures in the financial statements of IFIs.

The discussion on the features of CG mechanisms (i.e. board size, board independence, CEO duality; AC size, AC independence, AC expertise) as CG strength which is expected to affect the firm performance of Islamic bank and mediated by the disclosure. Generally, the board are decided by laws or Memorandum of Association (MOA) of the Islamic banking. It is knowledgeable to set a recommendation in term of board size within a certain range but not the exact number. The motivation behind the range is to maintain a strategic distance from unexpected conditions which could drive the board to disregard the laws. Term limits and constant achievement secure a constant balance of board of directors' size. There have been several studies in the literature reporting that the possibility of financial statement fraud to happen is higher when board size is large (Beasley, 1996; Dechow, Sloan, \& Sweeny, 1996). The larger board of directors size is related to lower effectiveness and decreasing firm performance because these may lead to problems in communication and coordination (Eisenberg, Sundgren, \& Wells, 1998). Nguyen, Rahman, Tong, and Zhao (2015) found a find strong evidence of a negative relationship between board size and firm performance of the companies. Company with a large board are associated with CEO compensation that is sensitive to company size, but not too firm performance. The compatible with the way that organisations with an expansive board likewise show bring down working execution and higher working expenses. Nevertheless, due to the concerns of Islamic bank in safeguarding stakeholders' rights, this paper argues that size of boards directors should be larger in order to represent the broader group of stakeholders in accordance with the Islamic CG model, as suggested by Bukair and Abdul-Rahman (2015), Al-Malkawi and Pillai (2018) and Bhatti and Bhatti (2009).

Many researchers have argued that the positive relationships between board independence and disclosure in annual report of company (Abdallah, Hassan, \& McClelland, 2015; Alnabsha, Abdou, Ntim, \& Elamer, 2017; Che Haat, Abdul Rahman, \& Mahenthiran, 2008; Cong \& Freedman, 2011; Haldar et al., 2018). There is positive the relationship between board independence with the transparency and disclosure of the company in Islamic banks (Haniffa \& Cooke, 2002). The better awareness to disclose more on CG information in the annual 
report when the board independent in the company are large. A better decision in regulating and monitoring the actions of top management can achieve when the more independent board in the company (Fuzi, Halim, \& Julizaerma, 2016). According to Laksmana (2008), more independent boards and compensation committees are more likely to make objective decisions by supporting greater disclosure.

Overseeing the audit process and managing the process of internal audit for the company are scope and responsibilities of AC. The larger of the AC, the more responsibility could be delegated to the committee and this similar to the arguments related to the board of directors. Thus, the lead to a higher level of disclosure, providing tough monitoring and affected the firm performance because of large AC size (Ben Barka \& Legendre, 2016; Detthamrong, Chancharat, \& Vithessonthi, 2017). Hence, this study proposes that large AC size persuades more transparency in the financial report of Islamic banking. AC independence promotes greater efficiency in the monitoring of internal controls and the financial reporting of the company (Barua, Rama, \& Sharma, 2010). The members of the AC independent are more likely want to maintain their own status, less responsible for being manipulated by the others whose interests might be served in an annual report submitted is biased. The members of the independent AC should also be more likely to report the annual report with a higher audit quality (Abbott, Park, \& Parker, 2000; Anderson, Mansi, \& Reeb, 2004; Klein, 2002).

Role duality in position exists when the chairperson of the board also holds the positions of the CEO in the company (Boyd, 1995). There are two options regarding the board leadership structure, it is CEO duality, and the other option is to separate the roles of CEO (Krause, Semadeni, \& Cannella, 2014). CEO duality has been supported by some theorists and regulators meanwhile in others theorists and regulators support the separation of roles. The role duality of CEO and chairman can create individual separation power that would affect the effective control exercised by the board that predicts by agency theory. For instance, Fama and Jensen (1983), Yang and Zhao (2014), Aktas (2018) and Wan Abdullah et al. (2015), all argued that, for a board to be effective, it is imperative to separate the chief executive and the chairman roles. The powerful CEOs may promote transparency about company activities for their private benefits (Deman, Jorissen, \& Laveren, 2018). This study proposes that the separations of role duality of CEO will encourage greater transparency through appropriate corporate disclosure, enhanced monitoring efficient control and affected the firm performance of the Islamic bank. This study has been totally up all the CG mechanisms to the CG score. Overall CG score is calculated for Islamic banking (the score will be totally up and become the CG strength).

\section{The relationship between Corporate Governance, Disclosure and Performance in Islamic banks}

The level of disclosure and transparency and timeliness of reporting on the annual report can be influenced by CG mechanism (Haniffa \& Cooke, 2002). The information disclosure in annual reports has been managing by the board of directors and management of the company (Hameed et al., 2016). The timeliness and quantity of information disclosure in the annual report are decided by the board of directors', especially voluntary items. The importance of transparency and disclosure factor (Haniffa \& Cooke, 2002) as well as timely reporting (Darmadi, 2013) in a relationship with CG, this study attempts to test whether CG mechanisms have a positive relationship with the level of transparency and disclosure of the Islamic bank's 
annual report. Then, in turn, a higher level of transparency and disclosure may be able to positively affect firm performances because of the reducing the cost of capital and information asymmetry as argued by Lang and Lundholm (2000) and Cui, Jo and Na (2018). There is a limited study on the CG disclosure as a mediating variable either in the company or banking sectors. According to Wan Abdullah et al. (2015), the influence stronger sets of CG mechanisms in Islamic banks are associated with a higher level of voluntary CG disclosure. Another study by Srairi (2015) found that Islamic banks with higher levels of CG disclosure can be affected the high operating performance measured by return on assets (ROA) and return on equity (ROE). Hence, based on this argument, it is expected that Islamic Banking with a higher level of CG mechanisms can be lead the disclosure in reporting and will gain better firm performance of Islamic banks.

The principles of Islamic banking place great emphasis on strong CG structure, transparency, the disclosure of information and strict adherence to Shari'ah principles. The Shari'ah governance framework is a set of organisational arrangements through which IFIs to ensure effective oversight, responsibility and accountability of the board of directors, management and Shari'ah committee (Hasan, 2011; Muneeza \& Hassan, 2014). The Shari'ah governance framework serves as a guide towards ensuring an operating environment that is compliant with Shari'ah principles at all times. Based on the definition of Shari'ah governance by IFSB (2009) no. 10, it can be observed that the extensive duties need to be performed by the SSB (Haqqi, 2014). Based on the understanding from the definition of Shari'ah principle, the duties of SSB is to oversight and supervise the Shari'ah compliance of the IFIs, as such, their competence is essential to form a robust Shari'ah board (Kasim et al., 2016). This definition also implies that the institution of the Shari'ah board is crucial to the Shari'ah governance system as an authoritative body ensuring Shari'ah compliance (Malkawi, 2013).

There is a limited previous study that measures the CG disclosures as a mediating variable in their study. Previous study only focus on the direct relationship (Al-Malkawi \& Pillai, 2018; Bukair \& Abdul Rahman, 2015; Elsiddig, 2017; Hakimi, Rachdi, Ben Selma Mokni, \& Hssini, 2018; Khamar Tazilah et al., 2017; Mallin et al., 2014; Mollah et al., 2014, 2016; Mollah \& Zaman, 2015; Nomran, Haron, \& Hassan, 2016).

\section{Conceptual Framework}

The following diagrammatic framework is developed. 


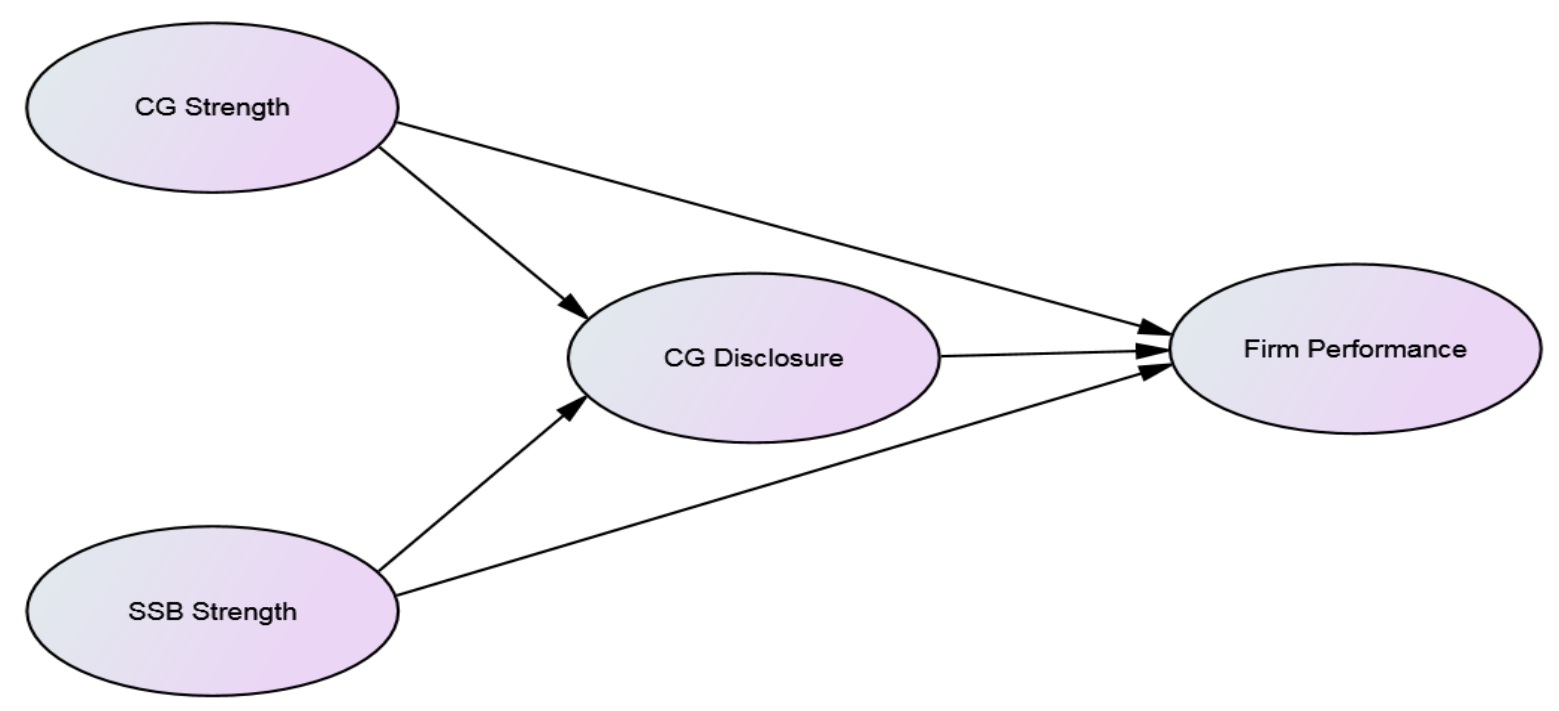

Figure 0.1: Proposed Conceptual Framework

\section{Methodology}

Content analysis of published articles and annual report was undertaken in order to identify the CG mechanisms, disclosure and firm performance of Islamic banks. Bell and Bryman (2007) define content analysis as a method that elaborates the documents and texts to quantify the content in terms of predetermined groupings to the contexts of their use. Many researchers have argued that this method is deemed to be appropriate on the disclosures studies (Haniffa \& Hudaib, 2006; Hassan \& Harahap, 2010; Maali, Casson, \& Napier, 2006; Mollah et al., 2016). The sample of this study consists of an Islamic bank located in the SEA and GCC regions. The selection of Islamic bank in the SEA and the GCC regions because the regions are among the progressive in Islamic finance and also among the first to establish IFIs.

\section{Research Variables and Measurement}

As per the review of the variables used in previous literature, table 4.1, this section will outline the selected variables of the three constructs; independent variables (CG strength and SSB strength) independent variable (firm performance) and lastly mediating variable (CG disclosures).

Table 4.1: Description of Variable used in this study

\begin{tabular}{|c|c|c|c|}
\hline Variable & \multicolumn{2}{|c|}{ Definitions and Coding } & Reference \\
\hline \multicolumn{4}{|c|}{ Panel A: Dependent Variable } \\
\hline \multirow{2}{*}{$\begin{array}{l}\text { Firm } \\
\text { Performance } \\
\text { of Islamic } \\
\text { banks }\end{array}$} & $\begin{array}{l}\text { Firm } \\
\text { Performance }\end{array}$ & ROA, ROE or Tobin's Q & $\begin{array}{l}\text { (Ammann, Oesch, \& } \\
\text { Schmid, 2011; Hamza, } \\
\text { 2013; Mollah et al., } \\
\text { 2014, 2016; Weiying } \\
\text { \& Baofeng, 2008) }\end{array}$ \\
\hline & $R O A$ & $\begin{array}{l}\text { Net income divided by total } \\
\text { asset }\end{array}$ & $\begin{array}{l}\text { (Abubakar Lahjie, } \\
\text { 2017; Kabir \& Thai, } \\
\text { 2017; Mollah \& } \\
\text { Zaman, } \\
\text { Platonova, 2014) }\end{array}$ \\
\hline
\end{tabular}




\begin{tabular}{|c|c|c|c|}
\hline & $R O E$ & $\begin{array}{l}\text { Net income divided by total } \\
\text { equity }\end{array}$ & $\begin{array}{l}\text { (Abubakar Lahjie, } \\
\text { 2017; Kabir \& Thai, } \\
\text { 2017; Mollah \& } \\
\text { Zaman, } \\
\text { Platonova, 2014) }\end{array}$ \\
\hline & Tobin's Q & $\begin{array}{l}\text { The market value of equity plus } \\
\text { book value of liability divided by } \\
\text { book value of the asset }\end{array}$ & $\begin{array}{l}\text { (Abubakar Lahjie, } \\
\text { 2017; Kabir \& Thai, } \\
\text { 2017; Mollah \& } \\
\text { Zaman, } \\
\text { Platonova, 2014) }\end{array}$ \\
\hline \multicolumn{4}{|c|}{ Panel B: Independent Variable } \\
\hline \multirow{3}{*}{$\begin{array}{l}\text { Corporate } \\
\text { Governance } \\
\text { Mechanisms }\end{array}$} & CG Strength & $\begin{array}{l}\text { Board size + Board independent } \\
+ \text { CEO duality }+A C \text { size }+A C \\
\text { independence }+ \text { Financial } \\
\text { expertise of } A C\end{array}$ & $\begin{array}{l}\text { (Hahn \& Lasfer, 2016; } \\
\text { Klein, 1998; Vafeas, } \\
\text { 1999; Wan Abdullah } \\
\text { et al., 2015) }\end{array}$ \\
\hline & Board Size & $\begin{array}{l}\text { Number of directors on the } \\
\text { board }\end{array}$ & $\begin{array}{l}\text { (Al-Nasser } \\
\text { Mohammed \& } \\
\text { Muhammed, 2017; } \\
\text { Basu \& Dimitrov, } \\
2010 ; \text { Douissa \& } \\
\text { Azrak, 2017; Grassa \& } \\
\text { Matoussi, 2014; Klein, } \\
\text { 2002; Lima } \\
\text { Crisóstomo, de Souza } \\
\text { Freire, \& Cortes de } \\
\text { Vasconcellos, 2011; } \\
\text { Upadhyay, Bhargava, } \\
\text { Faircloth, \& Zeng, } \\
\text { 2017; Weiying \& } \\
\text { Baofeng, 2008) }\end{array}$ \\
\hline & $\begin{array}{l}\text { Board } \\
\text { Independence }\end{array}$ & $\begin{array}{l}\text { The proportion of independent } \\
\text { directors }\end{array}$ & $\begin{array}{l}\text { lAl-Nasser } \\
\text { Mohammed \& } \\
\text { Muhammed, 2017; } \\
\text { Caprio, Laeven, \& } \\
\text { Levine, 2007; Che } \\
\text { Haat et al., 2008; } \\
\text { Evans, Evans, \& Loh, } \\
\text { 2002; Grassa \& } \\
\text { Matoussi, 2014; } \\
\text { Hamza, 2013; } \\
\text { Platonova, 2014) }\end{array}$ \\
\hline
\end{tabular}




\begin{tabular}{|c|c|c|c|}
\hline & CEO duality & $\begin{array}{l}0 \text { for CEO is also chair, } 1 \\
\text { otherwise }\end{array}$ & $\begin{array}{l}\text { (Dang A., Houanti, Le, } \\
\& \quad \text { Vu, 2017; } \\
\text { Fernandes, Farinha, } \\
\text { Martins, \& Mateus, } \\
\text { 2017; Grassa, 2016; } \\
\text { Yiwei Li, Gong, Zhang, } \\
\& \quad \text { Koh, 2017; } \\
\text { Platonova, 2014; } \\
\text { Rahman \& Bukair, } \\
\text { 2013; Wasiuzzaman \& } \\
\text { Nair Gunasegavan, } \\
\text { 2013) }\end{array}$ \\
\hline & AC Size & Number of directors in the $A C$ & $\begin{array}{l}\text { (Bhagat \& Bolton, } \\
\text { 2008; Brown \& Caylor, } \\
\text { 2009; Jiao, 2011; Wan } \\
\text { Abdullah et al., 2015) }\end{array}$ \\
\hline & $\begin{array}{l}\text { AC } \\
\text { Independence }\end{array}$ & $\begin{array}{l}\text { The proportion of independent } \\
\text { directors in the } A C\end{array}$ & $\begin{array}{l}\text { (Brown \& Caylor, } \\
\text { 2004; Chen, Cheng, \& } \\
\text { Wang, 2015; Klein, } \\
2002 ; \quad \text { Laksmana, } \\
2008)\end{array}$ \\
\hline & $\begin{array}{l}\text { AC Financial } \\
\text { Expertise }\end{array}$ & $\begin{array}{l}1 \text { for the number of SSB } \\
\text { members formally trained in } \\
\text { related economics or finance, } 0 \\
\text { otherwise }\end{array}$ & $\begin{array}{l}\text { (Brown \& Caylor, } \\
\text { 2004; Chen et al., } \\
\text { 2015; Klein, 2002; } \\
\text { Laksmana, 2008) }\end{array}$ \\
\hline \multirow{3}{*}{$\begin{array}{l}\text { SSB } \\
\text { Mechanisms }\end{array}$} & SSB Strength & $\begin{array}{l}\text { Number of SSB members + SSB } \\
\text { cross-memberships + Financial } \\
\text { expertise of the SSB }\end{array}$ & $\begin{array}{l}\text { (Wan Abdullah et al., } \\
\text { 2015) }\end{array}$ \\
\hline & SSB Size & Number of SSB members & $\begin{array}{l}\text { (Farook, Kabir Hassan, } \\
\text { \& Lanis, 2011; Grassa } \\
\text { \& Matoussi, 2014; } \\
\text { Kasim et al., 2016; } \\
\text { Mollah et al., 2014; } \\
\text { Platonova, 2014; } \\
\text { Rahman \& Bukair, } \\
\text { 2013; Samra, 2016; } \\
\text { Waemustafa } \\
\text { Abdullah, 2015) }\end{array}$ \\
\hline & $\begin{array}{l}\text { SSB Cross- } \\
\text { Memberships }\end{array}$ & $\begin{array}{l}\text { The average number of cross- } \\
\text { memberships of the SSB } \\
\text { members in institutions offering } \\
\text { Islamic financial services. }\end{array}$ & $\begin{array}{l}\text { (Farook et al., 2011; } \\
\text { Grassa, 2015; Grassa } \\
\text { \& Matoussi, 2014; } \\
\text { Kasim et al., 2016; } \\
\text { Mollah et al., 2014; } \\
\text { Nomran et al., 2016; } \\
\text { Platonova, 2014; } \\
\text { Rahman \& Bukair, } \\
\text { 2013; Samra, 2016; }\end{array}$ \\
\hline
\end{tabular}




\begin{tabular}{|c|c|c|c|}
\hline & & & $\begin{array}{l}\text { Waemustafa } \quad \& \\
\text { Abdullah, 2015) }\end{array}$ \\
\hline & $\begin{array}{l}\text { The expertise of } \\
\text { the SSB }\end{array}$ & $\begin{array}{l}1 \text { for the number of SSB } \\
\text { members formally trained in } \\
\text { related economics or finance, } 0 \\
\text { otherwise }\end{array}$ & $\begin{array}{l}\text { (Farook et al., 2011; } \\
\text { Grassa, 2015; Grassa } \\
\text { \& Matoussi, 2014; } \\
\text { Kasim et al., 2016; } \\
\text { Mollah et al., 2014; } \\
\text { Nomran et al., 2016; } \\
\text { Platonova, } \\
\text { Samra, } \\
\text { Waemustafa } \\
\text { Abdullah, 2015) }\end{array}$ \\
\hline \multicolumn{4}{|c|}{ Panel C: Mediating Variable } \\
\hline $\begin{array}{l}\text { Corporate } \\
\text { Governance } \\
\text { Disclosures }\end{array}$ & \multicolumn{2}{|c|}{$\begin{array}{l}\text { Disclosures index are selected based on the AAOIFI } \\
\text { governance standards, the IFSB on the CG } \\
\text { Guidelines, the OECD's Principles of CG (2015) and } \\
\text { the BCBS (2015) Paper. }\end{array}$} & $\begin{array}{l}\text { (Wan Abdullah, 2013; } \\
\text { Wan Abdullah et al. } \\
\text { 2015) }\end{array}$ \\
\hline
\end{tabular}

\section{Conclusions}

This research examines the effect of the CG strength and SSB strength to the financial performance of the Islamic bank. The CG strength has been measured based on the total CG mechanisms, and it is the same with measurement of the SSB strength. These technics are based on the study by Wan Abdullah, Percy, \& Stewart, (2015). The financial performance is quantified from ROA, ROE and Tobin's $Q$ based on measurement of accounting and marked based value. Based on the reviewed the past literature, we can conclude that a better CG mechanism will lead to a better firm performance of the Islamic bank. Besides that, the CG disclosure has an indirect effect on the CG mechanism and firm performance of an Islamic bank. The implementation of good CG will increase the efficiency and urge the economic growth. The presence of effective CG will help in increasing the trust level needed for the well-functioning financial sector, particularly in the capital market especially in the Islamic banking sectors.

The proposed study makes an original contribution to the literature since it is a limited comprehensive investigation into the combination of CG and SSB in affecting the firm performance of Islamic bank and CG disclosure as a mediating variable. Past literature only focuses on specific CG like board size, board independence, CEO duality and otherwise. These studies have been using combine CG mechanism and disclosure developed by the Wan Abdullah (2013), whereas this CG mechanism is more comprehensive for the disclosure on the Islamic bank. Past researchers have shown that CG is an important factor affecting the value or performance of a firm in the specific industry. This studies, which explicitly considers the differences in the social, economic and institutional variations because it is focused on the Islamic banking in the SEA and GCC region. 
INTERNATIONAL JOURNAL OF ACADEMIC RESEARCH IN BUSINESS AND SOCIAL SCIENCES

Vol. 8, No. 12, Dec, 2018, E-ISSN: 2222-6990 @ 2018 HRMARS

\section{References}

AAOIFI. (2010). Accounting and Auditing Organisation for Islamic Financial Institutions. Manama, Bahrain: Accounting and Auditing Organisation for Islamic Financial Institutions.

Abbott, L. J., Park, Y., \& Parker, S. (2000). The Effects of Audit Committee Activity and Independence on Corporate Fraud. Managerial Finance, 26(11), 55-68. https://doi.org/10.1108/03074350010766990

Abdallah, A. A. N., Hassan, M. K., \& McClelland, P. L. (2015). Islamic financial institutions, corporate overnance, and corporate risk disclosure in Gulf Cooperation Council countries. Journal of Multinational Financial Management, 31, 63-82. https://doi.org/10.1016/j.mulfin.2015.02.003

Abubakar Lahjie, A. (2017). The Impact of Corporate Governance, Corporate Social Responsibility and Information Quality on the Value of Indonesian Listed Firms. Victoria University.

Adams, R. B., Hermalin, B. E., \& Weisbach, M. S. (2010). The Role of Boards of Directors in Corporate Governance: A Conceptual Framework and Survey. Journal of Economic Literature, 48(1), 58107. https://doi.org/10.1257/jel.48.1.58

Ahmed, S., Zalailah, S., Hafiza, S., \& Hashim, A. (2016). Corporate Governance and Corporate Social Responsibility Disclosure of Islamic Banks : a Call for Additional Transparency, (Icabec), 1-8.

Aktas, N., Andreou, P. C., Karasamani, I., \& Philip, D. (2018). CEO Duality, Agency Costs, and Internal Capital Allocation Efficiency. British Journal of Management, 00, 1-21. https://doi.org/10.1111/1467-8551.12277

Al-Malkawi, H.-A. N., \& Pillai, R. (2018). Analyzing financial performance by integrating conventional governance mechanisms into the GCC Islamic banking framework. Managerial Finance, MF-052017-0200. https://doi.org/10.1108/MF-05-2017-0200

Al-Nasser Mohammed, S. A. S., \& Muhammed, J. (2017). The relationship between agency theory, stakeholder theory and Shariah supervisory board in Islamic banking. Humanomics, 33(1), 7583. https://doi.org/10.1108/H-08-2016-0062

Alkhamees, A. (2013). The impact of Shari'ah governance practices on Shari'ah compliance in contemporary Islamic finance. Journal of Banking Regulation, 14(2), 134-163. https://doi.org/10.1057/jbr.2012.12

Alnabsha, A., Abdou, H. A., Ntim, C. G., \& Elamer, A. A. (2017). Corporate Boards, Ownership Structures and Corporate Disclosures: Evidence from a Developing Country. Journal of Applied Accounting Research, 19(August), 1-46. https://doi.org/10.1108/JAAR-01-2016-0001

Ammann, M., Oesch, D., \& Schmid, M. M. (2011). Corporate governance and firm value: International evidence. Journal of Empirical Finance, 18(1), 36-55. https://doi.org/10.1016/j.jempfin.2010.10.003

Anderson, Mansi, S., \& Reeb, D. (2004). Board characteristics, accounting report integrity, and the cost of debt. Journal of Accounting and Economics, 37(3), 315-342. https://doi.org/10.1016/j.jacceco.2004.01.004

Ararat, M., Black, B. S. B., \& Yurtoglu, B. B. B. (2017). The effect of corporate governance on firm value and profitability: Time-series evidence from Turkey. Emerging Markets Review, 30(November 2014), 113-132. https://doi.org/10.1016/j.ememar.2016.10.001

Asutay, M., \& Harningtyas, A. F. (2016). Developing Maqasid al-Shari'ah Index to Evaluate Social Performance of Islamic Banks: A Conceptual and Empirical Attempt. International Journal of 
INTERNATIONAL JOURNAL OF ACADEMIC RESEARCH IN BUSINESS AND SOCIAL SCIENCES

Vol. 8, No. 12, Dec, 2018, E-ISSN: 2222-6990 @ 2018 HRMARS

Islamic Economics and Finance Studies, 1(1), 137-150. https://doi.org/10.25272/j.21498407.2017.3.2.10

Barua, A., Rama, D. V, \& Sharma, V. (2010). Audit committee characteristics and investment in internal auditing. Journal of Accounting and Public Policy, 29(5), 503-513. https://doi.org/10.1016/j.jaccpubpol.2010.09.001

Basel Committe on Banking Supervision. (2015). Corporate governance principles for banks. Bank for International Settlements. Retrieved from https://www.bis.org/bcbs/publ/d328.pdf

Basu, N., \& Dimitrov, O. (2010). Sarbanes-Oxley, governance, performance, and valuation. Journal of Financial Regulation and Compliance, 18(1), 32-45. https://doi.org/10.1108/13581981011019615

Beasley, M. S. (1996). An empirical analysis of the relation between the board of director composition and financial statement fraud. Accounting Review, 71(4), 443-465. https://doi.org/10.2307/248566

Bell, E., \& Bryman, A. (2007). The ethics of management research: An exploratory content analysis. British Journal of Management, 18(1), 63-77. https://doi.org/10.1111/j.14678551.2006.00487.x

Ben Barka, H., \& Legendre, F. (2016). Effect of the board of directors and the audit committee on firm performance: a panel data analysis. Journal of Management \& Governance, Forthcoming, 21(3), 1-19. https://doi.org/10.1007/s10997-016-9356-2

Bhagat, S., \& Bolton, B. (2008). Corporate governance and firm performance. Journal of Corporate Finance, 14(3), 257-273. https://doi.org/10.1016/j.jcorpfin.2008.03.006

Bhagat, S., \& Bolton, B. (2009). Corporate governance and firm performance: Recent evidence. Electronic Copy Available at: Http://Ssrn. Com/Abstract, 1361815(May), 1-57. Retrieved from https://www.researchgate.net/file.PostFileLoader.html?id=566526f47eddd339d78b4576\&ass etKey=AS\%3A303912039452672\%401449469684173

Bhatti, M., \& Bhatti, I. (2009). Development in legal Issues of Corporate Governance in Islamic Finance. Journal of Economic and Administrative Sciences, 25(1), 67-91. https://doi.org/10.1108/10264116200900004

Black, B., Carvalho, A. G. de, Khanna, V., Kim, W., \& Yurtoglu, B. (2016). Corporate Governance indices and construct validity. ECGI Working Paper Series in Finance. Retrieved from https://papers.ssrn.com/sol3/papers.cfm?abstract_id=2838273

Boyd, B. K. (1995). CEO duality and firm performance: A contingency model. Strategic Management Journal, 16(4), 301-312. https://doi.org/10.1002/smj.4250160404

Brown, L. D., \& Caylor, M. L. (2004). Corporate Governance and Firm Performance. SSRN Electronic Journal. https://doi.org/10.2139/ssrn.586423

Brown, L. D., \& Caylor, M. L. (2009). Corporate governance and firm operating performance. Review of Quantitative Finance and Accounting, 32(2), 129-144. https://doi.org/10.1007/s11156-0070082-3

Budiman, T., Kristanti, F. T., \& Wardhana, W. (2016). Islamic Bank Listed in Financial Market: Risk, Governance, Earning, and Capital. Al-lqtishad: Journal of Islamic Economics, 9(1), 1-12. https://doi.org/10.15408/aiq.v9i1.4011

Bukair, A. A., \& Abdul-Rahman, A. (2015). The Effect of the Board of Directors' Characteristics on 
INTERNATIONAL JOURNAL OF ACADEMIC RESEARCH IN BUSINESS AND SOCIAL SCIENCES

Vol. 8, No. 12, Dec, 2018, E-ISSN: 2222-6990 @ 2018 HRMARS

Corporate Social Responsibility Disclosure by Islamic Banks. Journal of Management Research, 7(2), 506-519. https://doi.org/10.5296/jmr.v7i2.6989

Bukair, A. A., \& Abdul Rahman, A. (2015). Bank performance and board of directors attributes by Islamic banks. International Journal of Islamic and Middle Eastern Finance and Management, 8(3), 291-309. https://doi.org/10.1108/IMEFM-10-2013-0111

Caprio, G., Laeven, L., \& Levine, R. (2007). Governance and bank valuation. Journal of Financial Intermediation, 16(4), 584-617. https://doi.org/10.1016/j.jfi.2006.10.003

Chapra, M. U., \& Habib, A. (2002). Corporate Governance in Islamic Financial Institutions. Occasional Paper No. 6, Jeddah, IRTI/IDB, 22(6), 1-170. https://doi.org/10.1002/jcaf.20374

Che Haat, M. H., Abdul Rahman, R., \& Mahenthiran, S. (2008). Corporate governance, transparency and performance of Malaysian companies. Managerial Auditing Journal (Vol. 23). https://doi.org/10.1108/02686900810899518

Chen, X., Cheng, Q., \& Wang, X. (2015). Does increased board independence reduce earnings management? Evidence from recent regulatory reforms. Review of Accounting Studies, 20(2), 899-933. https://doi.org/10.1007/s11142-015-9316-0

Cong, Y., \& Freedman, M. (2011). Corporate governance and environmental performance and disclosures. Advances in Accounting, 223(2), 232. https://doi.org/10.1016/j.adiac.2011.05.005

Cui, J., Jo, H., \& Na, H. (2018). Does Corporate Social Responsibility Affect Information Asymmetry? Journal of Business Ethics, 148(3), 549-572. https://doi.org/10.1007/s10551-015-3003-8

Dang A., R., Houanti, L., Le, N. T., \& Vu, M.-C. (2017). Does corporate governance influence firm performance? Quantile regression evidence from a transactional economy. Applied Economics Letters, 1-5. https://doi.org/10.1080/13504851.2017.1390309

Darmadi, S. (2013). Corporate governance disclosure in the annual report. Humanomics, 29(1), 4-23. https://doi.org/10.1108/08288661311299295

Dechow, P. M., Sloan, R. G., \& Sweeny, A. P. (1996). Causes and consequences of earnings manipulations: an analysis of firm subject enforcement action by the SEC. Contemporary Accounting Research, 13(1), 1-32. https://doi.org/10.1111/j.1911-3846.1996.tb00489.x

Deman, R., Jorissen, A., \& Laveren, E. (2018). Board Monitoring in a Privately Held Firm: When Does CEO Duality Matter? The Moderating Effect of Ownership. Journal of Small Business Management, 56(2), 229-250. https://doi.org/10.1111/jsbm.12251

Detthamrong, U., Chancharat, N., \& Vithessonthi, C. (2017). Corporate governance, capital structure and firm performance: Evidence from Thailand. Research in International Business and Finance, 42, 689-709. https://doi.org/10.1016/j.ribaf.2017.07.011

Douissa, I. Ben, \& Azrak, T. (2017). Did the Attitude of Banks Towards Corporate Social Responsibility Reporting Change Since the Last Global Financial Crisis? A Comparative Study of Conventional and Islamic Banks in the United Arab Emirates. International Journal of Economics and Financial Issues, 7(4), $468 . \quad$ Retrieved from http://search.proquest.com/openview/2676cab1b69c73c4a9e15edf25257c02/1?pqorigsite $=$ gscholar $\& \mathrm{cbl}=816338$

Eisenberg, T., Sundgren, S., \& Wells, M. T. (1998). Larger Board Size and Decreasing Firm Value in Small Firms. Journal of Financial Economics, 48(1), 35-54. https://doi.org/10.1016/S0304- 
INTERNATIONAL JOURNAL OF ACADEMIC RESEARCH IN BUSINESS AND SOCIAL SCIENCES

Vol. 8, No. 12, Dec, 2018, E-ISSN: 2222-6990 @ 2018 HRMARS

405X(98)00003-8

Elsiddig, A. I. (2017). The Impact of Corporate Governance on Islamic Banking Performance: The Case of UAE Islamic Banks. Journal of Banking \& Finance, 2017(09), 1-62. https://doi.org/10.5281/zenodo.889020

Erkens, D. H., Hung, M., \& Matos, P. (2012). Corporate governance in the 2007-2008 financial crisis: Evidence from financial institutions worldwide. Journal of Corporate Finance, 18(2), 389-411. https://doi.org/10.1016/j.jcorpfin.2012.01.005

Ernst \& Young. (2016). World Islamic Banking Competitiveness Report 2016. Ernst and Young. Retrieved from http://www.ey.com/Publication/vwLUAssets/ey-world-islamic-bankingcompetitiveness-report-2016/\$FILE/ey-world-islamic-banking-competitiveness-report2016.pdf

Evans, J., Evans, R., \& Loh, S. (2002). Corporate Governance and Declining Firm Performance. International Journal of Business Studies, 10(1), 1-18. Retrieved from http://web.a.ebscohost.com/ehost/pdfviewer/pdfviewer?vid=1\&sid=162f5a6d-d3fc-4bd2b1e5-e14b5e4ddee4\%40sessionmgr4010

Fama, E. F., \& Jensen, M. C. (1983). Agency Problems and Residual Claims. The Journal of Law and Economics, 26(2), 327-349. https://doi.org/10.1086/467038

Farag, H., Mallin, C., \& Ow-Yong, K. (2017, August). Corporate governance in Islamic banks: New insights for dual board structure and agency relationships. Journal of International Financial Markets, Institutions and Money. https://doi.org/10.1016/j.intfin.2017.08.002

Farook, S., Kabir Hassan, M., \& Lanis, R. (2011). Determinants of corporate social responsibility disclosure: the case of Islamic banks. Journal of Islamic Accounting and Business Research, 2(2), 114-141. https://doi.org/10.1108/17590811111170539

Fernandes, C., Farinha, J., Martins, F. V., \& Mateus, C. (2017). Supervisory boards, financial crisis and bank performance: Do board characteristics matter? Journal of Banking Regulation, 18(4), 310337. https://doi.org/10.1057/s41261-016-0037-5

Fuzi, S. F. S., Halim, S. A. A., \& Julizaerma, M. K. (2016). Board Independence and Firm Performance. Procedia Economics and Finance, 37, 460-465. https://doi.org/10.1016/S2212-5671(16)301526

Ghayad, R. (2008). Corporate governance and the global performance of Islamic banks. Humanomics, 24(3), 207-216. https://doi.org/10.1108/08288660810899368

Grais, W., \& Pellegrini, M. (2006). Corporate Governance in Institutions Offering Islamic Financial Services: Issues and Options. World Bank Policy Research Working Paper (Volume 405, Vol. October). Washington: World bank, Financial a. private sector development network. https://doi.org/http://dx.doi.org/10.1596/1813-9450-4052

Grassa, R. (2015). Shariah supervisory systems in Islamic finance institutions across the OIC member countries. Journal of Financial Regulation and Compliance, 23(2), 135-160. https://doi.org/10.1108/JFRC-02-2014-0011

Grassa, R. (2016). Corporate governance and credit rating in Islamic banks: Does Shariah governance matters? Journal of Management and Governance, 20(4), 875-906. https://doi.org/10.1007/s10997-015-9322-4

Grassa, R., \& Matoussi, H. (2014). Corporate governance of Islamic banks. International Journal of 
INTERNATIONAL JOURNAL OF ACADEMIC RESEARCH IN BUSINESS AND SOCIAL SCIENCES

Vol. 8, No. 12, Dec, 2018, E-ISSN: 2222-6990 @ 2018 HRMARS

Islamic and Middle Eastern Finance and Management, 7(3), 346-362. https://doi.org/10.1108/IMEFM-01-2013-0001

Hahn, P. D., \& Lasfer, M. (2016). Impact of foreign directors on board meeting frequency. International Review of Financial Analysis, 46, 295-308. https://doi.org/10.1016/j.irfa.2015.11.004

Haider, N., Khan, N., \& lqbal, N. (2015). Impact of corporate governance on firm performance in Islamic financial institution. International Journal of Technological Exploration and Learning, 51(2008), 106-110. https://doi.org/10.5539/ijef.v6n6p1

Hakimi, A., Rachdi, H., Ben Selma Mokni, R., \& Hssini, H. (2018). Do board characteristics affect bank performance? Evidence from the Bahrain Islamic banks. Journal of Islamic Accounting and Business Research, 9(2), 251-272. https://doi.org/10.1108/JIABR-06-2015-0029

Haldar, A., Shah, R., Nageswara Rao, S. V. D., Stokes, P., Demirbas, D., \& Dardour, A. (2018). Corporate performance: does board independence matter? - indian evidence. International Journal of Organizational Analysis, 26(2018), 1-24. https://doi.org/10.1108/IJOA-12-2017-1296

Hameed, S., Wirman, A., Alrazi, B., Nazli, M., Pramono, S., Mohd Nor, M. N., \& Pramono, S. (2016). Alternative Disclosure and Performance Measures for Islamic Banks. Second Conference on Administrative Sciences: Meeting the Challenges of the Globalization Age, King Fahd University of Petroleum \& Minerals, Dhahran, Saudi Arabia, 1-30. https://doi.org/10.1017/CBO9781107415324.004

Hamza, H. (2013). Sharia governance in Islamic banks: effectiveness and supervision model. International Journal of Islamic and Middle Eastern Finance and Management, 6(3), 226-237. https://doi.org/10.1108/IMEFM-02-2013-0021

Haniffa, R., \& Cooke, T. (2002). Culture, corporate governance and disclosure in Malaysian corporations. Abacus, 38(3), 317-349. https://doi.org/10.1111/1467-6281.00112

Haniffa, R., \& Hudaib, M. (2006). Corporate governance structure and performance of Malaysian listed companies. Journal of Business Finance and Accounting, 33(7-8), 1034-1062. https://doi.org/10.1111/j.1468-5957.2006.00594.x

Haqqi, A. R. A. (2014). Shari'ah governance in Islamic financial institution: An appraisal. US-China Law Review, 11, 112-113. https://doi.org/ISSN 1985-7497

Hasan, Z. (2011). A survey on Shari'ah governance practices in Malaysia, GCC countries and the UK: Critical appraisal. International Journal of Islamic and Middle Eastern Finance and Management, 4(1), 30-51. https://doi.org/10.1108/17538391111122195

Hassan, A., \& Harahap, S. S. (2010). Exploring corporate social responsibility disclosure: the case of Islamic banks. International Journal of Islamic and Middle Eastern Finance and Management, 3(3), 203-227. https://doi.org/10.1108/17538391011072417

IFSB. (2009). Guiding Principles on Shari'ah Governance Systems for Institutions Offering Islamic Financial Services. Islamic Financial Service Board. Kuala Lumpur. Retrieved from http://www.ifsb.org/standard/IFSB-10 Shariah Governance.pdf

Jiao, Y. (2011). Corporate Disclosure, Market Valuation, and Firm Performance. Financial Management (Blackwell Publishing Limited), 40(3), 647-676. https://doi.org/10.1111/j.1755053X.2011.01156.X

Kabir, R., \& Thai, H. M. (2017). Does corporate governance shape the relationship between corporate 
INTERNATIONAL JOURNAL OF ACADEMIC RESEARCH IN BUSINESS AND SOCIAL SCIENCES

Vol. 8, No. 12, Dec, 2018, E-ISSN: 2222-6990 @ 2018 HRMARS

social responsibility and financial performance? Pacific Accounting Review, 29(2), 227-258. https://doi.org/10.1108/PAR-10-2016-0091

Kasim, N., Nu Nu Htay, S., \& Ahmed Salman, S. (2016). Empowering the Shari'ah Committee towards Strengthening Shari'ah Governance Practices in Islamic Financial Institutions. Review of European Studies, 8(2), 142. https://doi.org/10.5539/res.v8n2p142

Khamar Tazilah, M. D. A., Ahamad Rapani, N., Abdul Halim, N., \& Majid, M. (2017). Preliminary Study on The Compliance of Shariah Governance Framework and Performance of Islamic Financial Institutions in Malaysia. In The 19th Malaysian Finance Association Annual Conference (MFAC). Kampar, Perak, Malaysia.

Klein, A. (1998). Firm Performance and Board Committee Structure. The Journal of Law and Economics, 41(1), 275-304. https://doi.org/10.1086/467391

Klein, A. (2002). Audit committee, board of director characteristics, and earnings management. Journal of Accounting and Economics, 33(3), 375-400. https://doi.org/10.1016/S01654101(02)00059-9

Krause, R., Semadeni, M., \& Cannella, A. A. (2014). CEO Duality: A Review and Research Agenda. Journal of Management, 40(1), 256-286. https://doi.org/10.1177/0149206313503013

Kusuma, H., \& Ayumardani, A. (2016). the Corporate Governance Efficiency and Islamic Bank Performance : an Indonesian Evidence. Polish Journal of Management Studies, 13(1), 111-120. https://doi.org/10.17512/pjms.2016.13.1.11

Laksmana, I. (2008). Corporate board governance and voluntary disclosure of executive compensation practices. Contemporary Accounting Research, 25(4), 1147-1182. https://doi.org/10.1506/car.25.4.8

Lang, M. H., \& Lundholm, R. J. (2000). Voluntary Disclosure and Equity Offerings: Reducing Information Asymmetry or Hyping the Stock? Contemporary Accounting Research, 17(4), 623662. https://doi.org/10.1506/9N45-F0JX-AXVW-LBWJ

Li, Y., Armstrong, A., \& Clarke, A. (2014). Relationships of Corporate Governance Mechanisms and Financial Performance in Islamic Banks: a Meta-analysis. Journal of Business Systems, Governance and Ethics, 9(1), 50-64. Retrieved from http://vuir.vu.edu.au/30216/1/613-1386-1SM.pdf

Li, Y., Gong, M., Zhang, X., \& Koh, L. (2017). The impact of environmental, social, and governance disclosure on firm value: The role of CEO power. The British Accounting Review. https://doi.org/10.1016/j.bar.2017.09.007

Lima Crisóstomo, V., de Souza Freire, F., \& Cortes de Vasconcellos, F. (2011). Corporate social responsibility, firm value and financial performance in Brazil. Social Responsibility Journal, 7(2), 295-309. https://doi.org/10.1108/17471111111141549

Maali, B., Casson, P., \& Napier, C. (2006, June). Social reporting by islamic banks. Abacus. https://doi.org/10.1111/j.1467-6281.2006.00200.x

Malkawi, B. (2013). Shari'ah Board in the Governance Structure of Islamic Financial Institutions. American Journal of Comparative Law, 61(3), 539. https://doi.org/10.1093/ajcl/61.3.539

Mallin, C., Farag, H., \& Ow-Yong, K. (2014). Corporate social responsibility and financial performance in Islamic banks. Journal of Economic Behavior \& Organization, 103(March 2013), S21-S38. https://doi.org/10.1016/j.jebo.2014.03.001 
INTERNATIONAL JOURNAL OF ACADEMIC RESEARCH IN BUSINESS AND SOCIAL SCIENCES Vol. 8, No. 12, Dec, 2018, E-ISSN: 2222-6990 @ 2018 HRMARS

Mollah, S., Hassan, M. K., \& Al-Farooque, O. (2014). Corporate Governance, Risk-Taking and Firm Performance of Islamic Banks During Global Financial Crisis. Finance and Development in Islamic Economies Conference, 1-36.

Mollah, S., Hassan, M. K., Al Farooque, O., \& Mobarek, A. (2016). The governance, risk-taking, and performance of Islamic banks. Journal of Financial Services Research, 51(2), 195-219. https://doi.org/10.1007/s10693-016-0245-2

Mollah, S., \& Zaman, M. (2015). Shari'ah supervision, corporate governance and performance: Conventional vs. Islamic banks. Journal of Banking and Finance, 58, 418-435. https://doi.org/10.1016/j.jbankfin.2015.04.030

Muneeza, A., \& Hassan, R. (2014). Shari'ah corporate governance: the need for a special governance code. Corporate Governance: The International Journal of Business in Society, 14(1), 120-129. https://doi.org/10.1108/CG-02-2011-0015

Naushad, M., \& Malik, S. A. (2015). Corporate governance and bank performance: A study of selected banks in GCC region. Asian Social Science, 11(9), 226-234. https://doi.org/10.5539/ass.v11n9p226

Nguyen, P., Rahman, N., Tong, A., \& Zhao, R. (2015). Board size and firm value: evidence from Australia. Journal of Management \& Governance, 20(4), 851-873. https://doi.org/10.1007/s10997-015-9324-2

Nienhaus, V. (2003). Governance of Islamic Banks. Handbook of Islamic Banking, 128-143. Retrieved from

https://books.google.com/books?hl=en\&lr=\&id=jvTtDzD5uFQC\&oi=fnd\&pg=PA128\&dq=nienh aus+2007+islamic+banks\&ots=75eP9mNWwu\&sig=9RI45kMWaWX5_aibkHgWbG6zWv4

Nomran, N., Haron, R., \& Hassan, R. (2016). Shari'ah Supervisory Board Characteristics Effects On Islamic Banks' Performance: Evidence from Malaysia. In 4th ASEAN International Conference on Islamic Finance (AICIF 2016) (p. 16). IIUM Institute of Islamic Banking and Finance.

Noordin, N. H., Kassim, S., Prabangasta, D., \& Hayeeyahya, N. (2015). Does Composition of Shariah Committee Influence Shariah Governance Disclosure ? Evidence from Islamic Banks in Malaysia. IIUM Institute of Islamic Banking and Finance, Malaysia, 31. Retrieved from https://www.researchgate.net/profile/Salina_Kassim/publication/279986922_Does_Compositi on_of_Shariah_Committee_Influence_Shariah_Governance_Disclosure_Evidence_from_Islami c_Banks_in_Malaysia/links/55a200f608ae1c0e04641607/Does-Composition-of-Shariah-Commi Organisation for Economic Cooperation and Development. (2015). G20/OECD Principles of Corporate Governance. OECD Publishing. https://doi.org/10.1787/9789264236882-en

Platonova, E. (2014). Corporate Analysis of CSR Dis/cosure and Its Impact on Flnancial Performance in the GCC Islamic Banks. University of Durham. Retrieved from http://etheses.dur.ac.uk/10726/1/ELENA_PLATONOVA-E-THESIS.pdf?DDD2+

Rahman, A. A., \& Bukair, A. A. (2013). The influence of the Shariah supervision board on corporate social responsibility disclosure by Islamic banks of Gulf Co-operation Council countries. Asian Journal of Business and Accounting, 6(2), 65-105. https://doi.org/10.5296/jmr.v7i2.6989

Ratri, R. F., \& Dewi, M. (2017). The Effect of Financial Performance and Environmental Performance on Firm Value with Islamic Social Reporting (ISR) Disclosure as Intervening Variable in Companies Listed at Jakarta Islamic Index (JII). SHS Web of Conferences, 34(4), 12003. 
INTERNATIONAL JOURNAL OF ACADEMIC RESEARCH IN BUSINESS AND SOCIAL SCIENCES

Vol. 8, No. 12, Dec, 2018, E-ISSN: 2222-6990 @ 2018 HRMARS

https://doi.org/10.1051/shsconf/20173412003

Samra, E. (2016). Corporate Governance in Islamic Financial Institutions. Law Commons of International Immersion Program Papers, No.22, 1-18. Retrieved from http://chicagounbound.uchicago.edu/

Srairi, S. (2015). Corporate governance disclosure practices and performance of Islamic banks in GCC countries. Journal of Islamic Finance, 4(2), 1-17. Retrieved from https://www120.secure.griffith.edu.au/rch/items/6cee4a04-7c00-4303-ac9c-e22f89b1733e/1/

Thajudeen, K. S. (2013). Issues in Corporate Governance in Islamic Financial Institutions : A case study on Bank Islam. INCEIF Working Paper, 1-15. Retrieved from https://www.academia.edu/3571681/Issues_in_Corporate_Governance_in_Islamic_Financial_ Institutions

Upadhyay, A. D., Bhargava, R., Faircloth, S., \& Zeng, H. (2017). Inside directors, risk aversion, and firm performance. Review of Financial Economics, 32, 64-74. https://doi.org/10.1016/j.rfe.2016.12.001

Vafeas, N. (1999). Board meeting frequency and firm performance. Journal of Financial Economics, 53(1), 113-142. https://doi.org/10.1016/S0304-405X(99)00018-5

Waemustafa, W., \& Abdullah, A. (2015). Mode of Islamic Bank Financing: Does Effectiveness of Shariah Supervisory Board Matter? Australian Journal of Basic and Applied Sciences, 9(37)(37), 6. Retrieved from https://papers.ssrn.com/sol3/papers.cfm?abstract_id=2769667

Wan Abdullah, W. A. (2013). Determinants of Corporate Governance Disclosure Practices of Islamic Banks. Griffith University, Brisbane. Retrieved from https://www120.secure.griffith.edu.au/rch/file/6cee4a04-7c00-4303-ac9ce22f89b1733e/1/Wan Abdullah_2013_02Thesis.pdf

Wan Abdullah, W. A., Percy, M., \& Stewart, J. (2015). Determinants of voluntary corporate governance disclosure: Evidence from Islamic banks in the Southeast Asian and the Gulf Cooperation Council regions. Journal of Contemporary Accounting and Economics, 11(3), 262279. https://doi.org/10.1016/j.jcae.2015.10.001

Wan Ibrahim, W. H., Ismail, A. G., \& Wan Mohd Zabaria, W. N. (2011). Disclosure, risk and performance in islamic banking: A panel data analysis. International Research Journal of Finance and Economics, 72, 100-114. Retrieved from https://ukm.pure.elsevier.com/en/publications/disclosure-risk-and-performance-in-islamicbanking-a-panel-data-a

Wasiuzzaman, S., \& Nair Gunasegavan, U. (2013). Comparative study of the performance of Islamic and conventional banks. Humanomics, 43-60. https://doi.org/10.1108/08288661311299312

Weiying, J. I. a, \& Baofeng, C. (2008). Corporate Governance and its Effects on Firm Value. Industry Cluster and Meta-Studies --- Proceedings of International Conference on Industry Cluster Development and Management, 436-440. Retrieved from http://www.seiofbluemountain.com/en/search/index.php?key=Corporate+Governance+and+i ts+Effects+on+Firm+Value \&x=25\&y=16

Yang, T., \& Zhao, S. (2014). CEO duality and firm performance: Evidence from an exogenous shock to the competitive environment. Journal of Banking and Finance, 49, 534-552. 
INTERNATIONAL JOURNAL OF ACADEMIC RESEARCH IN BUSINESS AND SOCIAL SCIENCES Vol. 8, No. 12, Dec, 2018, E-ISSN: 2222-6990 @ 2018 HRMARS

https://doi.org/10.1016/j.jbankfin.2014.04.008 